\title{
Early diagnosis of abnormal development of preterm newborns: assessment instruments
}

\author{
Rosana S. Santos, ${ }^{1}$ Alexandra P. Q. C. Araújo, ${ }^{2}$ Maria Amelia S. Porto ${ }^{2}$
}

\begin{abstract}
Objective: To review the literature regarding screening psychomotor tests for the early identification of developmental problems.

Sources: A search on SciELO, PubMed and Google Scholar was performed using the terms "prematurity," "developmental delay," "cerebral palsy," "early diagnosis" and "evaluation tests."

Summary of the findings: A total of 455 references were listed, and 174 studies were selected for this review based on title, relevance, and abstract. Only original and electronically available material, from 1985 forward, with information on design, applicability, and psychometric properties of those tests was included.

Conclusions: Screening tests are important to speed the beginning of treatment measures in order to allow for better developmental outcome. Among the many tests that can be employed for this purpose, the DENVER II and the Alberta Infant Motor Scale are the most often used in Brazilian studies. The Movement Assessment of Infants is starting to be used in our country. Two other tests are recommended in the literature due to their high sensibility and specificity: the Test of Infant Motor Performance and the General Movements.
\end{abstract}

J Pediatr (Rio J). 2008;84(4):289-299: Prematurity, motor delay, early diagnostic, screening tests.

\section{Introduction}

In the last few years the incidence of preterm births has grown considerably. Better support care provided to pregnant women and the great technological improvement of the equipment used in the neonatal intensive care units (NICU) increased the possibility of survival for these babies. ${ }^{1,2}$ Preterm newborns present with several associated comorbidities such as long-term ventilatory support, bronchopulmonary dysplasia, cerebral hemorrhage and jaundice that contribute to increase the risk of developmental impairments. ${ }^{3-5}$ The direct and indirect consequences related to prematurity can cause damages that impair the child's future development. ${ }^{2}$

1. Mestranda, Universidade Federal do Rio de Janeiro (UFRJ), Rio de Janeiro, RJ, Brazil. Professora auxiliar, Fisioterapia, UFRJ, Rio de Janeiro, RJ, Brazil.

2. Professora adjunta, Neuropediatria, UFRJ, Rio de Janeiro, RJ, Brazil.

No conflicts of interest declared concerning the publication of this article.

Suggested citation: Santos RS, Araújo AP, Porto MA. Early diagnosis of abnormal development of preterm newborns: assessment instruments. J Pediatr (Rio J). 2008;84(4):289-299.

Manuscript received Mar 11 2008, accepted for publication May 142008.

doi:10.2223/JPED.1815 
Table 1 - Number of studies found for each one of the developmental screening test

\begin{tabular}{|c|c|c|c|c|c|}
\hline Tests & General & Brazil & Preterm & Brazil Preterm & Used in this review \\
\hline DENVER II & 55 & 14 & 11 & 5 & 20 \\
\hline AIMS & 35 & 10 & 20 & 6 & 22 \\
\hline MAI & 12 & 2 & 6 & 2 & 9 \\
\hline GM & 61 & 1 & 27 & 1 & 12 \\
\hline TIMP & 16 & 0 & 13 & 0 & 19 \\
\hline Total & 179 & 26 & 77 & 14 & 79 \\
\hline
\end{tabular}

AIMS = Alberta Infant Motor Scale; GM = General Movements; MAI = Movement Assessment of Infants; TIMP = Test of Infant Motor Performance.

Approximately $30 \%$ of the preterm children develop severe motor impairments and are often diagnosed with cerebral palsy. The rates of neuromotor disorders can reach as much as $50 \%$ of the very low birth weight preterm children $(\leq 1,500 \mathrm{~g})$ and the extremely low birth weight preterm children $(\leq 1,000 \mathrm{~g}) \cdot{ }^{1,2,6,7}$ Several studies have demonstrated that not only those children at high risk suffer impairments in the future. Preterm children at low risk for developmental deficits have shown difficulties related to other developmental areas besides the motor area. ${ }^{5,8-11}$

Studies involving preterm children at school age have found a higher incidence of learning disorders, attention deficits, hyperactivity and behavioral problems in this population. ${ }^{12-14}$ These future impairments can be reduced with early intervention. Screening for detection of abnormalities and developmental risks makes it easier to establish a therapeutic intervention, especially while the child is growing and his/her neuropsychomotor development is not fully achieved. ${ }^{15,16}$ Several elements related to the characteristics of prematurity and its comorbidities are used to determine the developmental risk. However, such factors do not guarantee the existence of developmental impairment. ${ }^{17-20}$

In the city of Rio de Janeiro, a large portion of the follow-up care services for preterm newborns use development scales in an informal fashion and do not use standardized diagnostic measures that have been proven to be efficient for the assessment of movements and the definition of abnormality markers. In addition, there are few standardized assessment instruments for the early detection of problems in the Brazilian population, ${ }^{21}$ which leads health professionals to use standardized measures designed for foreign populations, even though there are no Brazilian studies confirming whether the characteristics of such instruments are appropriate for the native population.

The objective of this study is to review the literature in order to critically analyze the main characteristics and properties of the tests most often used to detect developmental disorders. As a result of this review, we intend to provide the foundation for future normative studies using such tests, as well as to make information available to support the choice of an assessment instrument for clinical practice in Brazil.

\section{Sources}

A review of the literature was performed including the studies published during the last 25 years on the databases SciELO, CAPES platform, PubMed and Google Scholar. The key words used in this survey were: prematurity, developmental delay, cerebral palsy, early diagnosis, and evaluation tests. These key words were found in Brazilian and international journals.

\section{Summary of the findings}

Four hundred and fifty-five titles were found. Of these, 174 studies were selected to be included in this review. The studies were selected based on their title, relevance and abstract. All articles are electronically available. We only used studies available from 1985 that fulfilled the need for information on design, applicability and psychometric properties of the screening tests.

Among the several tests used in Brazilian studies for assessment of development, the Bayley Scales of Infant Development II and the Denver Developmental Screening Test II are two of the most commonly used (Table 1 ).

The Bayley II Scale is an updated version of the test comprising the analysis of three subscales: mental, motor and behavioral. It is a standardized scale that has been validated for the North American population, and it is mainly recommended for the early diagnosis of abnormalities. However, since the main focus of the present literature review is to analyze the screening scales, the Bayley II will not be discussed here. ${ }^{14,22}$ 
The Denver is basically a developmental screening test, and even though it was designed many years ago, its version used in the most recent studies is a reviewed and updated version taking into consideration recent changes. Other tests, which have been based on more current developmental theories, have also been designed with this purpose during the last 2 decades. The Alberta Infant Motor Scale (AIMS) and the Movement Assessment of Infants (MAI) are assessment instruments based on more recent developmental theories that have been used in Brazilian researches. In addition to these instruments, other two scales (the Test of Infant Motor Performance - TIMP and the General Movements - GM) have demonstrated sensitivity for the early detection of abnormalities according to the literature. These tests were designed to identify problems in the first months of life, mainly to screen abnormalities in preterm newborns.

\section{Description of the tests}

\section{Denver II}

The Denver Developmental Screening Test was designed by Frankenburg \& Dodds in 1967 (Colorado, USA). It has been widely used for screening children with developmental delay. Although it was adapted and validated to be used in several countries, this instrument has received severe criticism because some of its items are difficulty to administer, there are few items for some areas and there have been sociocultural changes since the instrument was designed. In addition, the original version provided unreliable scoring and administration methods considering the current standards, what made it difficult to use the test in researches. As a consequence of these problems, a new version of the test was designed. ${ }^{22,23}$ The Denver Developmental Screening Test II is the most recent version, and it has the purpose of assessing and identifying children at risk for developmental delay (Table 2).

The items are administered directly to the child, or the guardians answer the questions (Table 3 ). ${ }^{21-24}$ The test is easy to perform and provides a training and guidance manual regarding its use. It can be administered by several health professionals and, therefore, it is one of the tests most commonly used to screen developmental delays even in Brazil. ${ }^{22,24-33}$ Although the test has not been validated for our population, an informal cultural adaptation has been carried out to make its administration easier. ${ }^{24}$

Another advantage is the wide age group reached by this test, which makes a long-term follow-up of child development possible. This new version of the test was also carefully standardized and validated for the population of the State of Colorado, USA, and it seems to have higher sensitivity regarding the identification of delay in comparison with the first version, mainly in terms of language acquisition. ${ }^{23,34-36}$
One of the disadvantages highlighted by the researchers is the fact that, since the test was not designed with the purpose of diagnosing delays, but to guide the care provided to the child, its results present little prognostic value, especially for those cases with a small number of failing responses. ${ }^{22,25-27,36-40}$ Even though the test reaches a wide age group and allows for the longitudinal follow-up of development, it does not seem to be sufficient to assess qualitative changes over time and perform early detection of subtle psychomotor alterations. ${ }^{22,26,29}$

\section{MAI}

The Movement Assessment of Infants is often used by therapists in the USA. The test was designed by Chandler and two other pediatric physical therapists in 1980 and it was based on clinical experience and on literature review about normal child development. Its purpose is to assess the motor development of children up to 1 year old at high risk for motor disorders aiming at contributing to establish the bases for early intervention. ${ }^{41,42}$ This test was also designed to follow the effects of physical therapy, as well as to provide support for researches serving as an assessment instrument. ${ }^{36,42}$ It requires specific skills from the assessor and intense handling of the child. The test consists in the assessment of tonus, primitive reflexes, automatic responses of straightening, balance and self-protection, in addition to voluntary movements resulting from visual and auditory stimuli or through the manifestation of motor landmarks. ${ }^{36,43}$ It is advisable that the professional intending to administer the test receive accurate training. The MAI should be used by physical and occupational therapists who provide pediatric care, but it can be administered by several health professionals with experience in child development. ${ }^{36,43}$ Each questionable score is a risk point to classify the child as normal or questionable. When summed up, these points offered a total risk criterion; the higher the score, the higher the risk for developmental delay (Table 3). ${ }^{42,43}$ Although the authors of the test did not design a normative scale, there are risk profiles for $4,6,8$ and 12 months of age. ${ }^{36,42-44}$

The criteria established in the initial study were questioned in later studies carried out by Harris et al. ${ }^{45}$ who have demonstrated moderate reliability and questioned the cutoff points proposed, suggesting new cutoff points for total risk. ${ }^{39}$ In subsequent studies, other authors agreed with these findings. ${ }^{46-48}$ The predictive and simultaneous validity was also checked in a sample of high-risk children, with $81 \%$ of identification at 4 months in children diagnosed with cerebral palsy later (Table 2), but a significant number of false-positive (44\%) was found, which led the researchers to the conclusion that, although there is significant correlation with cerebral palsy for some items, only a moderate correlation is verified when the total risk score is used. ${ }^{39,43,44,46}$ The lack of risk criteria for other ages also impairs the use of the test in researches. Other important criticism associated with the test 
Table 2 - Main characteristics of the screening tests

\begin{tabular}{|c|c|c|c|c|c|}
\hline Test & Aspects assessed & Age group & $\begin{array}{c}\text { Time of } \\
\text { administration }\end{array}$ & $\begin{array}{c}\text { Validation in } \\
\text { Brazil }\end{array}$ & Reliability \\
\hline \multirow[t]{2}{*}{ DENVER } & Motor & $0-6$ years & 20 minutes & No & Inter-rater: 0.99 \\
\hline & Behavioral language & & & & Test-retest: 0.90 \\
\hline \multirow[t]{4}{*}{ MAI } & Motor & 0-1 year & $60 / 90$ minutes & No & Inter-rater: 0.72 \\
\hline & & & & & Test-retest: 0.76 \\
\hline & & & & & Sensitivity: $81 \%$ (4 m) \\
\hline & & & & & Specificity: $44 \%$ \\
\hline \multirow[t]{5}{*}{ AIMS } & Motor & $0-18$ months & 20 minutes & No & Inter-raters: 0.96-0.99 \\
\hline & & & & & Test-retest: 0.86-0.99 \\
\hline & & & & & Correlation: $r=0.97-0.99$ \\
\hline & & & & & Sensitivity: $77.3-86.4 \%(4 \mathrm{~m})$ \\
\hline & & & & & Specificity: $65.5 \%$ (8 m) \\
\hline \multirow[t]{3}{*}{ GM } & Motor & $\begin{array}{c}\text { Preterm to } 20 \mathrm{w} \\
\text { postterm }\end{array}$ & $10 / 50$ minutes & No & Inter-rater: $92-97 \%$ \\
\hline & & & & & Sensitivity: $100 \%$ \\
\hline & & & & & Specificity: 96\% \\
\hline \multirow[t]{4}{*}{ TIMP } & Motor & $\begin{array}{c}32 \text { w GA - } 4 \\
\text { months }\end{array}$ & $30 / 45$ minutes & No & Inter-rater: 0.95 \\
\hline & & & & & Test-retest: 0.89 \\
\hline & & & & & Sensitivity: 0.92 \\
\hline & & & & & Specificity: 0.76 \\
\hline
\end{tabular}

AIMS = Alberta Infant Motor Scale; GA = gestational age; GM = General Movements; MAI = Movement Assessment of Infants; TIMP $=$ Test of Infant Motor Performance; $w=$ weeks.

is the verification that some items are unnecessarily tested at some ages, which results in a test longer than necessary. Such aspects of the test impair the measurement of the child's skills evolution over time, restricting the use of the instrument as a tool to follow the therapeutic intervention. ${ }^{39,42,43}$ These findings have also been observed in a study performed in Brazil. The authors of this study have found results similar to the ones previously reported by other investigators. Even though the instrument has not been validated to the Brazilian population, it has been used to investigate and follow the development of populations at risk. ${ }^{42,49}$
Finally, although the authors suggest the possibility of use by other health professionals, some items are difficult to be performed by professionals who do not work directly with child rehabilitation. ${ }^{36,41}$

\section{AIMS}

The Alberta Infant Motor Scale was designed to follow the development of normal children up to 18 months old. In 1994, Piper \& Darrah, two Canadian physical therapists, designed the instrument that included the neuromaturational theories and the dynamic aspects of motor development. Differently 
Table 3 - Scoring system and criteria of normality

\begin{tabular}{|c|c|c|}
\hline Tests & Scoring System & Criteria of normality \\
\hline \multirow[t]{3}{*}{ DENVER II } & $\begin{array}{l}\text { Items administered to the child or answer provided by } \\
\text { guardians }\end{array}$ & $\begin{array}{l}\text { Normal: child is able to perform expected activities ( } 1 \text { failure } \\
\text { per area) }\end{array}$ \\
\hline & Item classification: successfully performed, failure or refusal & $\begin{array}{l}\text { Suspected: failure to perform the activities executed by } \\
75-95 \% \text { of the children ( } \geq \text { two failures in more than two } \\
\text { areas) }\end{array}$ \\
\hline & & $\begin{array}{l}\text { Delay: failure to perform the activities executed by more } \\
\text { than } 90 \% \text { of the children }\end{array}$ \\
\hline \multirow[t]{6}{*}{ MAI } & Items administered to the child & Total risk score (4 months) \\
\hline & Score on a numerical scale for total risk score & Low risk: $\leq 10$ points \\
\hline & Tonus & \\
\hline & 1-2 = hypotonia; $3=$ normal; 4-5 = hypertonia & Intermediate risk: $>10 \leq 13$ points \\
\hline & $6=$ both hypotonia and hypertonia & High risk: $>13$ points \\
\hline & $\begin{array}{l}\text { Other items (ordinal progression): } 1=\text { mature; } 2-3= \\
\text { immature; } 4=\text { normal }\end{array}$ & \\
\hline \multirow[t]{5}{*}{ AIMS } & Spontaneously performed items & Normal: 25-90 percentile \\
\hline & Dichotomic scoring & \\
\hline & Present $=1$ & Suspected: below 10 percentile over 6 months \\
\hline & Absent $=0$ & High risk: 10 percentile at 4 months \\
\hline & Final score applied to a percentile scale & 5 percentile at 8 months \\
\hline \multirow[t]{4}{*}{ GM } & GM videotaped for classification & Normal: presence of torsion/irregular movements \\
\hline & Classification based on presence and frequency & Risk: poor or chaotic repertoire of GM \\
\hline & Location and intensity of GM & Presence of cramped-synchronised GMs \\
\hline & & Absence of fidgety movements or abnormal movements \\
\hline \multirow[t]{3}{*}{ TIMP } & Observed items (13) and administered items (29) & Normal: intermediate score (Mean \pm 1 SD) \\
\hline & Score on ordinal numerical scale & Suspected: low score $(<-1>-2$ SD) \\
\hline & Final score applied to the normative scale & High risk: very low score $(<-2$ SD) \\
\hline
\end{tabular}

AIMS = Alberta Infant Motor Scale; GM = General Movements; MAI = Movement Assessment of Infants; SD = standard deviation; TIMP = Test of Infant Motor Performance.

from other instruments previously designed, the AIMS was created to fulfill the necessity of pediatric therapists regarding the selection and follow-up of the sequential motor development. ${ }^{50}$
The assessment is performed based on the free observation of the child in four positions: supine (nine items), prone (21 items), sitting (12 items) and standing (16 items). The test assesses how long the child keeps the position, the 
anti-gravitational posture and the child's ability to independently change positions. ${ }^{50,51}$ Its design allows for the gradual quantification of the development, since the scale increases the repertoire of expected responses as the child grows up. In the initial study $(n=2,203)$ exclusively carried out in the province of Alberta, Canada, the validity and reliability of the instrument were established. These results have been confirmed by other authors in subsequent studies. The simultaneous validity with other tests have demonstrated good correlation, sensitivity and specificity rates (Table 2). ${ }^{37,51-55}$

The authors have established cutoff points in order to classify the child within a risk profile, demonstrating higher sensitivity for the identification in children older than 6 months (Table 3). ${ }^{50}$ These findings have been checked in other studies, and the results confirmed high sensitivity rate, but the best specificity and accuracy rates were associated with results with a percentile $\leq 5 .{ }^{37,56-59}$ Even though these results have been reported in most studies, some researches that analyzed the items of the test have demonstrated difficulties to assess the efficacy of the results. In a study performed by Liao \& Campbell, the authors have found that, even though the test increases the level of difficulty of the responses over time, only one more point in the score can significantly change the percentile, which causes important alterations in some ages and irrelevant alterations in others. ${ }^{59}$ These findings suggest the existence of important gaps in the increase of difficulties in terms of the items evolution. These gaps have been identified in some positions at the initial ages and in the expected ability to stand up in older children. It suggests that the results can be questionable, impairing the clinical use of the assessment instrument. As a consequence of the contradictory results, these researchers have suggested the additional use of other items to adequate the level of difficulty, in addition to the necessity of further studies to define the clinical importance of the assessment. ${ }^{59-63}$ Another issue that has been pointed out by some researchers is related to the differences found in the mean of the results for foreign populations. The studies have demonstrated that the common profile found was below the normative sample proposed by the authors of the test, which means that there is need for further studies that can identify the causes of these differences. ${ }^{56,57,63-65}$

The AIMS is considered to be a quick test that is easy to administer, having a guidance manual available. The authors state that there is no need of training for physical and occupational therapists who work with children, but they recommend that other health professionals are trained by skilled professionals, which requires a longer period of training so that safe administration of the test is achieved. ${ }^{63}$ Although the instrument has not been validated in Brazil, a cultural adaptation of the scoring instrument has been performed. Such instrument has been used to screen abnormalities in children, and it has been proven to be a useful instrument in the follow-up of infants at risk being treated with early intervention. ${ }^{54,63,65-70}$

\section{GM}

The assessment of general movements was designed to perform early detection of abnormalities in the development of preterm babies and term children at risk. The test is based on the observation of the child's spontaneous movements without external intervention or stimulus. Such observation is performed by videotaping the child laying in the supine position while she/he is awake, resting in the incubator or on bed. ${ }^{71}$

The test recommends that the assessment is performed after the third day of life, at three different moments between the preterm period and the postterm period up to 20 weeks. Special recommendations are made regarding the position and the stimuli that should be avoided so that there is no interference in the child's observation. The child cannot be upset or crying, and a pacifier cannot be used to calm the child down. These behaviors and accessories can change the expression of spontaneous movements and impair the assessment. ${ }^{71}$

The GM was designed based on the long-term observation of spontaneous motor behaviors recorded in children at risk. The studies that originated the assessment have been carried out by European researchers in the 1970s and they provided great contribution to the understanding of the initial development of preterm and term children. The great interest in the development and the lack of satisfaction with the assessment measures commonly used led Prechtl, the main researcher, to analyze in detail the spontaneous motor behavior of these babies. Using the recorded images, it is possible to identify and establish the patterns of expected movements in the first months of life, as well as to define which ones are compatible with the child's future development. ${ }^{71}$

Prechtl has identified and described the motor patterns of newborns' typical movements. These movements change as the baby grows, evolving from torsion movements (writing movements) to irregular and elegant movements (fidgety), establishing a complex and harmonious network of motor experimentation, gradually changed by voluntary attitudes. Based on these findings, the researcher and her colleagues have found that the absence or abnormalities of general movements and the presence of simultaneous spasms (cramped synchronized) constitute an abnormal motor behavior and establish the risk for the future development of the baby (Table 3 ). ${ }^{71-76}$

Since this test is based solely on visual observation, it has received some criticism because it allows for differences in the results when the same child is observed by different assessors. The training necessary for the practical administration of the test is quite expensive and requires greater efforts from those interested in administering it. Recent studies have demonstrated that with appropriate training the differences can 
be reduced and the results reach excellent reliability rates (Table 2). ${ }^{71,75-78}$

The GM is a qualitative and non-invasive assessment that has proven to be efficient to perform the early detection of abnormalities at 3 months of age. ${ }^{16,77-80}$ The studies including this assessment have demonstrated high correlation with cerebral palsy in the future when there are cramped synchronized and absence of normal fidgety movements. ${ }^{77-82}$

\section{TIMP}

The Test of Infant Motor Performance was designed to assess posture and control of the selective functional movement. It has been developed with the purpose of identifying motor delay or deficit in preterm children and helping with the planning of goals of intervention in these babies. The child can be assessed while in the neonatal ICU as long as she/he presents stable clinical conditions, without signs of stress (stage 4 of Brazelton Scale). The test was initially designed to be performed by physical and occupational therapists who work directly with movements and who are experienced in early intervention in children at risk.

The items of the current test are based on the natural demands triggered by the babies and their caregivers, therefore, showing ecological validity. The most recent version of the test was designed with illustrative photos so that it can be used as an educational tool for parents regarding the babies' evolution. ${ }^{83-86}$

The first version of the test, which was proposed by Girolami \& Campbell (USA), comprised 43 items and was designed for a study about the effectiveness of treatment in high-risk preterm children in 1983 . The instrument was developed based on motor learning theories that highlighted the importance of stability and guidance of alignment in space and are related to the environmental interaction and the individual's self-organization neuromotor changes. The test was also organized based on the principles of other tests previously known in the scientific field. Currently, Campbell keeps carrying out investigations in order to analyze and improve the test. The most recent version of this test is a result of several studies and changes proposed based on the analytical results of the items and the collaboration of co-researchers. ${ }^{83,86}$

The items of the instrument focus the assessment on the development of head control and selective limb control, assessing the typical motor repertoire of the first quarter of life in different positions in space, using visual and auditory stimuli. 83,86

The score increases as the child shows greater voluntary and postural control. Therefore, the test assures an increase in the level of difficulty of the response regarding the child's expected evolution according to age. The final scores are transferred to a table showing the classification according to age (Table 3 ). ${ }^{83,86,87}$ This test has proven to be sensitive to behavioral changes and therapeutic intervention, being able to differentiate between children with different levels of alterations for a poor motor result. ${ }^{88,89}$

The test was validated based on the sample selected, keeping appropriate proportions of gender and race in order to agree with the diversity of the North American population. Reliability and sensitivity were checked during validation and showed excellent results in the third month. The most recent studies have confirmed these findings, but have demonstrated moderate specificity for developmental disorders (Table 2). ${ }^{83,84,90-95}$

Recently, a study involving several regions has been conducted with the purpose of determining the standard ages for the clinical administration of the test and possible differences between the groups of risk, confirming that the standards are appropriate to be used with the general population. ${ }^{96}$ Further studies continue to investigate the association of the items with other findings from the standard neurological test and the specific association at different ages and the development of cerebral palsy. ${ }^{97-100}$

\section{Conclusions}

Many tests are used to screen abnormalities; however, five of these tests can be identified as being the most frequently administered in researches. Among the most popular tests in Brazil, the Denver II and the AIMS stand out. Both were designed to follow the development of normal children, but are more often used to screen developmental deviations. These tests are easy and quick to administer, and an easily understandable manual is provided to facilitate their administration. However, the Denver II has not been compared with other tests and presents low sensitivity for children younger than 8 months old. The AIMS has been validated with other tests and shows good sensitivity for children older than 6 months old, but a more detailed analysis of the properties of its items raises doubts about the adequacy of the level of difficulty for some ages, questioning the predictive value of the test for older ages.

The MAI is a test designed to identify abnormalities and to follow the early intervention. It also requires that the assessor is experienced and skilled. It does not provide normative scales, only suggesting reference criteria for some ages. It seems to be sensitive to identify abnormalities at 4 months; nevertheless, the studies performed using the test have demonstrated only moderate specificity. In addition, deeper studies on the test have identified difficulties in terms of increase of difficulties of the items over time, which arises doubts about the use of this tool as a follow-up instrument during intervention.

The TIMP and the GM are more focused on the qualitative assessment of movements, offering the best reliability and 
sensitivity rates at early ages ( 3 months). Their administration is quite time consuming and depends on the child's behavioral state. These tests require accurate training with moderate cost of administration and certification of the professionals. Since their main purpose is the identification of early abnormalities (before 4 months), they do not provide elements that can be used as a tool for the child's long-term follow-up.

All screening instruments have advantages and disadvantages. The choice of one instrument will depend on the population and the objectives the health professional intends to achieve. The shortage of standardized Brazilian instruments highlights the importance of conducting studies in Brazil in order to check the adequacy and validation of the instruments regarding local standards.

\section{References}

1. Rugolo LM. Crescimento e desenvolvimento a longo prazo do premature extreme. J Pediatr (Rio J). 2005;81:S101-10.

2. Murphy N, Such-Neibar T. Cerebral Palsy diagnosis and management: the state of the art. Curr Probl Pediatr Adolesc Health Care. 2003;33:146-69.

3. da Silva ES, Nunes ML. The influence of gestational age and birth weight in the clinical assessment of the muscle tone of healthy term and preterm newborns. Arq Neuropsiquiatr. 2005;63: 956-62.

4. Sullivan MC, Margaret MM. Perinatal morbidity, mild motor delay, and later school outcomes. Dev Med Child Neurol. 2003;45: 104-12.

5. Short EJ, Klein NK, Lewis BA, Fulton S, Eisengart S, Kercsmar C, et al. Cognitive and academic consequences of bronchopulmonary dysplasia and very low birth weight: 8-year-old outcomes. Pediatrics. 2003;12:359-66.

6. Morton RE.Diagnosis and classification of cerebral palsy. Current Paediatrics. 2001;11:64-67.

7. Surveillance of Cerebral Palsy in Europe. Surveillance of cerebral palsy in Europe: a collaboration of cerebral palsy surveys e registers. Surveillance of Cerebral Palsy in Europe (SCPE). Dev Med Child Neurol. 2000;42:816-24.

8. Zaw W, Gagnon R, Silva O. The risks adverse neonatal outcome among preterm small for gestational age infants according to neonatal versus fetal growth standards. Pediatrics. 2003;111: 1430-1.

9. Magalhães LC, Catarina PW, Barbosa VM, Mancini MC, Paixão ML. A comparative study of the perceptual and motor performance at school age of preterm and full term children. Arq Neuropsiquiatr. 2003;61:250-5.
10. Foulder-Hughes LA, Cooke RW. Motor, cognitive, and behavioural disorders in children born very preterm. Dev Med Child Neurol. 2003;45:97-103.

11. Stjernqvist K, Svenningsen NW. Ten-years follow-up of children born before 29 gestational weeks: health, cognitive development, behaviour and school achievement. Acta Paediatr. 1999;88:557-62.

12. Caravale B, Tozzi C, Albino G, Vicari S. Cognitive development in low risk preterm infants at 3-4 years of life. Arch Dis Child Fetal Neonatal Ed. 2005;90:F474-9.

13. Marlow N. Neurocognitive outcome after very preterm birth. Arch Dis Child Fetal Neonatal Ed. 2004;89:F224-8.

14. Hack M, Taylor HG, Drotar D, Schulchter M, Cartar L, Wilson-Costello D, et al.Poor predictive validity of the Bayley Scales of Infant Development for cognitive function of extremely low birth weight children at school age. Pediatrics. 2005;116: 333-41.

15. Sand N, Silverstein M, Glascoe FP, Gupta VB, Tonniges TP, O'Connor KG. Pediatricians reported practices regarding developmental screening: do guidelines work? Do they help? Pediatrics. 2005;116:174-9.

16. Palmer FB. Strategies for the early diagnosis of cerebral palsy. J Pediat. 2004;145:S8-11.

17. Mello RR, Dutra MV, Silva KS, Lopes JM. Valores de predição da avaliação neurológica ultra-sonográfica cerebral neonatal em relação ao desenvolvimento de prematuros de muito baixo peso. Rev Saude Publica. 1998;32:5.

18. Mello RR, Meio MD, Morsch DS, Silva KS, Dutra MV, Monteiro AV, et al. Ultra-sonografia cerebral neonatal normal no prematuro - é possível tranqüilizar os pais? J Pediatr (Rio J). 1999;75:45-9.

19. Paczko N, Rotta NT, Silva A, Leiria F. Hipercogenicidade dos vasos talâmicos no recém-nascido prematuro. J Pediatr (Rio J). 2002; 78:371-4.

20. Hope PL, Gould SJ, Howard S, Hamilton PA, Costello AM, Reynolds ER. Precision of ultrasound diagnosis of pathologically verified lesions in the brains of very preterm infants. Dev Med Child Neurol. 1988;30:457-71.

21. Magalhães LC, Barbosa VM, Araújo AR, Paixão ML, Figueiredo EM, Gontijo AP. Análise do desempenho de crianças pré-termo no Teste de Desenvolvimento de Denver nas idades de 12, 18 e 24 meses. Pediatria (São Paulo). 1999;21:330-9.

22. Brenneman SK. Testes de desenvolvimento do bebê e da criança. In: Tecklin JS. Fisioterapia pediátrica. $3^{a}$ ed. Porto Alegre, RS: Artmed; 2002. p. 42-8.

23. Frankenburg WK, Dodds J, Archer P, Shapiro H, Bresnick BThe Denver II: a major revision and restandardization of the Denver Developmental Screening Test.. Pediatrics. 1992;89:91-7.

24. Halpern R, Barros FC, Horta BL, Victora CG. Desenvolvimento neuropsicomotor aos 12 meses de idade em uma coorte de base populacional no Sul do Brasil: diferenciais conforme peso ao nascer e renda familiar. Cad Saude Publica. 1996;12 Supl 1:73-8.

25. Pilz EM, Schermann LB.Determinantes biológicos e ambientais do desenvolvimento neuropsicomotor em uma amostra de crianças de Canoas/RS. Cien Saude Coletiva. 2007;12:181-90.

26. Fisberg M, Pedromonico MR, Braga JA, Ferreira AM, Pini C, Campos SC, et al. Comparação do desempenho de pré-escolares, mediante teste de desenvolvimento de Denver, antes e após intervenção nutricional. Rev Assoc Med Bras. 1997; 43:99-104. 
27. Rezende MA, Beteli VC, Santos JL.Avaliação de habilidades de linguagem e pessoal-sociais pelo Teste de Denver II em instituições de educação infantil. Acta Paul Enferm. 2005;18: 56-63.

28. Kreling KC, Brito AS, Matsuo T.Fatores perinatais associados ao desenvolvimento neuropsicomotor de recém-nascidos de muito baixo peso. Pediatria (São Paulo). 2006;28:98-108.

29. Dias BR, Piovesana AM, Montenegro MA, Guerreiro MM. Desenvolvimento neuropsicomotor de lactentes filhos de mães que apresentaram hipertensão arterial na gestação. Arq Neuropsiquiatr. 2005;63:632-6.

30. Victora CG, Barros FC, Tomasi E, Menezes AM, Horta BL, Weiderpass $E$, et al. Tendência e diferenciais na saúde materno-infantil: delineamento e metodologia das coortes de 1982 e 1993 de mães e crianças de Pelotas, Rio Grande do Sul. Cad Saude Publica. 1996;12:7-14.

31. Rezende MA, Beteli VC, Santos JL.Follow-up of the child's motor abilities in day-care centers and pré-schools. Rev Latino-am Enferm. 2005;13:619-25.

32. Halpern R, Giugliani ER, Victora CE, Barros FC, Horta BL. Fatores de risco para suspeita de atraso no desenvolvimento neuropsicomotor aos 12 meses de vida. J Pediatr (Rio J). 2000; 76:421-8.

33. Bruck I, Tahan TT, Cruz CR, Martins LT, Antoniuk SA, Rodrigues $M$, et al. Developmental milestones of vertically HIV infected and seroreverters children - follow up of 83 children. Arq Neuropsiquiatr. 2001;59:691-5.

34. Tahan TT, Bruck I, Burger M, Cruz CR. Neurological profile and neurodevelopment of 88 children infected with HIV and 84 seroreverter children followed from 1995 to 2002. Braz J Infect Dis. $2006 ; 10: 322-6$.

35. Schirmer CR, Portuguez MW, Nunes ML. Clinical assessment of language development in children at age 3 years that were born preterm. Arq Neuropsiquiatr. 2006;64:926-31.

36. Frankenburg WK. Preventing developmental delays: is developmental screening sufficient? Pediatrics. 1994;93: 586-92.

37. Lee LL, Harris SR.Psychometric properties and standardization samples of four screening tests for infants and young children: a review. Pediatr Phys Ther. 2005;17:140-7.

38. Kerfeld CI, Mark RG, Stewart KB. Evaluation of the Denver II as applied to Alaska native children. Pediatric Physical Therapy. 1997;9:23-31.

39. Miller V, Onotera RT, Deinard AS.Denver Developmental Screening Test: cultural variations in Southeast Asia. J Pediatr. 1996;104:481-2.

40. Drachler ML. Medindo o desenvolvimento infantil em estudos epidemiológicos: dificuldades subjacentes. J Pediatr (Rio J). $2000 ; 76: 401-3$.

41. Harris SR, Brady DK. Infant neuromotor assessments instruments: a review. In: Sweeney JK. The high-risk neonate: developmental therapy perspectives. Binhhamton, NY: Haworth Press, 1986. p. 135-8.

42. Lacerda TT, Magalhães LC. Análise da validade dos itens do Movement Assessment of Infants - MAI - para crianças pré-termo. Rev Bras Saude Mater Infant. 2006;6:297-308.

43. Salokorpi T, Rajantie I, Kivikko I, Haajanen R, Rajantie J. Predicting neurological disorders in infants with extremely low birth weight using the movement assessment of infants. Pediatr Phys Ther. 2001;13:106-9.
44. Harris SR, Heriza CB. Measuring infant movement. Clinical ant technological assessment techniques. Phys Ther. 1987;67: 1877-80.

45. Harris SR, Swanson MW, Andrews MS, Selis CJ, Robinson NM, Bennett FC, et al. Predictive validity of the "Movement Assessment of Infants". J Dev Behav Pediatr. 1984;5:336-42.

46. Magalhães LC, Amorim FP, Paixão ML, Barbosa VM, Mancini MC. Influência de fatores de risco biológico nos escores de um teste para detecção de paralisia cerebral em crianças pré-termo. Arq Bras Paralisia Cerebral. 2004;1:41-8.

47. Rose-Jacobs R, Cabral H, Beeghly M, Brown ER, Frank DA.The Movement Assessment of Infants (MAI) as a predictor of two-year neurodevelopmental outcome for infants born at term who are at social risk. Pediatr Phys Ther. 2004;16:212-21.

48. Grunau RE, Whitfield MF, Fay T, Holsti L, Oberlander T, Rogers ML. Biobehavioural reactivity to pain in preterm infants: a marker of neuromotor development. Dev Med Child Neurol. 2006;48:471-6.

49. Cardoso AA, Magalhães LC, Amorim RH, Paixão ML, Mancini MC, Rossi LD.Validade preditiva do Movement Assessment of Infants para crianças pré-termo brasileiras. Arq Neuropsiquiatr. 2004; 62:1052-7.

50. Darrah J, Piper M, Watt MJ. Assessment of gross motor skills of at-risk infants: predictive validity of the Alberta Infant Motor Scale. Dev Med Child Neurol. 1998;40:485-91.

51. Piper MC, Darrah J. Motor assessment of the developing infant. Philadelphia: W. B. Saunders; 1994.

52. Bartlett DJ, Okun NB, Byrne PJ, Watt JM, Piper MC. Early motor development of breech-and cephalic-presenting infants. Obstet Gynecol. 2000;95:425-32.

53. Dudeck-Shriber L, Zelazny S. The effects of prone positioning on the quality and acquisition of developmental milestones in four-month-old infants. Pediatr Phys Ther. 2007;19:48-55.

54. Bartlett DJ, Kneale Fanning JE. Relationships of equipment use and play positions to motor development at eight months corrected age on infants born preterm. Pediatr Phys Ther. 2003; 15:8-15.

55. Lee LL, Harris S. Psychometric properties and standardization samples of four screening tests for infants and young children: a review. Pediatr Phys Ther. 2005;17:140-7.

56. Campos D, Santos DC, Gonçalves VM, Goto MM, Arias AV, Brianeze AC, et al. Agreement between scales for screening and diagnosis of motor development at 6 months. J Pediatria (Rio J). 2006;82:470-4.

57. Fleuren KM, Smit LS, Stijnen T, Hartman A. New values for the Alberta Infant Motor Scale need to be established. Acta Paediatr. 2007;96:424-7.

58. Van Haastert IC, de Vries LS, Helders PJ, Jongmans MJ. Early gross motor development of preterm infants according to the Alberta Infant Motor Scale. J Pediatr. 2006;149:617-22.

59. Liao PJ, Campbell SK.Examination of the item structure of the Alberta Infant Motor Scale. Pediatr Phys Ther. 2004;16:31-8.

60. Fetters L, Tronick EZ.Discriminate power of the Alberta Infant Motor Scale and the Movement Assessment of Infants for prediction of Peabody Gross Motor Scale Scores of infants exposed in utero to cocaine. Pediatr Phys Ther. 2000;12:16-23.

61. Darrah J, Redfern L, Maguire TO, Beaulne AP, Watt J. Intra-individual stability of rate of gross motor development in full-term infants. Early Hum Dev. 1998;52:169-79. 
62. Cameron EC, Maehle V, Reide J. The effects of an early physical therapy intervention for very preterm, very low birth weight infants: a randomized controlled clinical trial. Pediatr Phys Ther. 2005;17:107-19.

63. Jeng SF, Yau KI, Chen LC, Hsiao SF. Alberta Infant Motor Scale: reliability and validity when used on preterm infants in Taiwan. Phys Ther. 2000;80:168-78.

64. Blanchard Y, Neilan E, Busanich J, Garavuso L, Klimas D. Interrater reliability of early intervention providers scoring the Alberta Infant Motor Scale. Pediatr Phys Ther. 2004;16:13-8.

65. Campos D, Santos DC, Gonçalves VM, Montebello MI, Goto MM, Gabbard C. Postural control of small for gestational age infants born at term. Rev Bras de Fisioter. 2007;11:7-12.

66. Formiga CK, Pedrazzani ES, Tudella E. Desenvolvimento motor de lactentes pré-termo participantes de um programa de intervenção fisioterapêutica precoce. Rev Bras Fisioter. 2004;8: 239-45.

67. Silva PL, Santos DC, Gonçalves VM.Influência de práticas maternas no desenvolvimento motor de lactentes do $6^{\circ}$ ao $12^{\circ}$ meses de vida. Rev Bras Fisioter. 2006; 10:252-31.

68. Mancini MC, Teixeira S, Araújo LG, Paixão ML, Magalhães LC, Coelho ZA, et al. Estudo do desenvolvimento da função motora aos 8 e 12 meses de idade em crianças nascidas pré-termo e a termo. Arq Neuropsiquiatr. 2002;60:974-80.

69. Schertz M, Zuk L, Zin S, Nadam L, Schwartz D, Bienkowski RS. Motor and cognitive development at one-year follow-up in infants with torticollis. Early Hum Dev. 2008;84:9-14.

70. Manacero S, Nunes ML. Evaluation of motor performance of preterm newborns during the first months of life using the Alberta Infant Motor Scale (AIMS). J Pediatr (Rio J). 2008;84:53-9.

71. Einspieler C, Prechtl HF, Bos AR, Ferrari F, Cioni G.Prechtl's method on the qualitative assessment of general movements in preterm, term and young infants. Cambridge: Cambridge University Press; 2004.

72. Prechtl HF, Einspieler C, Cioni G, Bos AF, Ferrari F, Sontheimer $D$. An early marker for neurological deficits after perinatal brain lesions. Lancet. 1997;349:1361-3.

73. Einspieler C, Prechtl HF, Ferrari F, Cioni G; Bos AF. The qualitative assessment of general movements in preterm, term and young infants - review of the methodology. Early Hum Dev. 1997;50: 47-60.

74. Bos AF, van Loon AJ, Hadders-Algra M, Martijn A, Okken A, Prechtl $\mathrm{H}$. Spontaneous motility in preterm, small-for-gestational ages infants. II. Qualitative aspects. Early Hum Dev. 1997;50: 131-47.

75. Hadders-Algra M. Evaluation of motor function in young infants by means of the assessment of general movements: a review. Pediatr Phys Ther. 2001;13:27-36.

76. Valentin T, Uhl K, Einspieler C. The effectiveness of training in Prechtl's method on the qualitative assessment of general movements. Early Hum Dev. 2005;81:623-7.

77. Adde L, Rygg M, Lossius K, Oberg GK, Stoen R.General Movement Assessment: predicting cerebral palsy in clinical practice. Early Human Dev. 2007;83:13-8.

78. Hadders-Algra M, Groothuis AM. Quality of general movements in infancy in related to neurological dysfunction, ADHD and aggressive behaviour. Dev Med Child Neurol. 1999;41:381-91.

79. Prechtl HF. General movement assessment as a method of developmental neurology: new paradigms and their consequences. The 1999 Ronnie MacKeith lecture. Dev Med Child Neurology. 2001;43:836-42.
80. Ferrari F, Cioni G, Einspieler C, Roversi M, Bos AF, Paolicelli PB, et al. Cramped synchronized general movements in preterm infants as an early marker for later cerebral palsy. Arch Pediatric Adolesc Med. 2002;156:460-7.

81. Garcia JM, Gherpelli JL, Leone CR. The role of spontaneous general movement assessment in the neurological outcome of cerebral lesions in preterm infants. J Pediatr (Rio J). 2004;80: 296-304.

82. Zuk L, Harel S, Leitner Y, Fattal-Valeviski A. Neonatal general movements: an early predictor for neurodevelopmental outcome in infants with intrauterine growth retardation. J Child Neurol. 2004; $19: 14-8$

83. Campbell SK, Kolobe TH, Osten ET, Lenke M, Girolami GL. Construct validity of infant motor performance. Phys Ther. 1995; 75:585-56

84. Murney ME, Campbell SK. The ecological relevance of the Test of Infant Motor Performance elicited scale items. Phys Ther. 1998; 8:479-89.

85. Campbell SK. Test-retest reliability of the test of infant motor performance. Pediatr Phys Ther. 1999;11:60-6.

86. Campbell SK. The test of infant motor performance: test user's manual version 1.4. Chicago, Ill: Infant Motor Performance Scales; 2001

87. Campbell SK, Wright BD, Linacre JM. Development of a functional movement scale for infants. J Appl Meas. 2002;3: 190-204.

88. Girolami G, Campbell SK. Efficacy of a neuro-developmental treatment program motor control of preterm infants. Pediatr Phys Ther. 1994;6:175-84.

89. Lekskulchai R, Cole J. Effect of a developmental program on motor performance in infants born preterm. Aust J Physiother. 2001;47:169-76.

90. Campbell SK, Kolobe TH. Concurrent validity of the Test of Infant Motor Performance with the Alberta Infant Motor Scale. Pediatr Phys Ther. 2000;12:2-9.

91. Campbell SK, Hedeker D. Validity of the Test of Infant Motor Performance for discriminating among infants with varying risk for poor motor outcome. J Pediatr. 2001;139:546-51.

92. Campbell SK, Kolobe TH, Wright BD, Linacre JM. Validity of the Test of Infant Motor Performance for prediction of 6-, 9- and 12 -month scores on the Alberta Infant Motor Scale. Dev Med Child Neurol. 2002;44:263-72.

93. Flegel J, Kolobe TH. Predictive validity or the Test of Infant Motor Performance as measured by the Bruininks-Oseretsky Test of Motor Proficiency at school age. Phys Ther. 2002; 82:762-71.

94. Kolobe TH, Bulanda M, Susman L. Predicting motor outcome at preschool age for infants tested at $7,30,60$, and 90 days after term age using the Test of Infant Motor Performance. Phys Ther. 2004;84:1144-56.

95. Barbosa VM, Campbell SK, Sheftel D, Singh J, Beligere N. Longitudinal performance of infants with cerebral Palsy on the Test Infant Motor Performance and on the Alberta Infant Motor Scale. Phys Occup Ther Pediatr. 2003;23:7-29.

96. Campbell SK, Levy P, Zawacki L, Liao PJ. Population-based age standards for interpreting results on the test of motor infant performance. Pediatr Phys Ther. 2006;18:119-25.

97. Barbosa VM, Campbell SK, Smith E, Berbaum M. Comparison of Test of Infant Motor Performance (TIMP) item responses among children with cerebral palsy, developmental delay, and typical development. Am J Occup Ther. 2005;59:446-56. 
98. Barbosa VM, Campbell SK, Berbaum M. Discriminating Infants from different developmental outcome groups using the Test of Infant Motor Performance (TIMP) item responses. Pediatr Phys Ther. 2007;19:28-39.

99. Lekskulchai $\mathrm{R}$, Cole J. The relationship between the scarf ratio and subsequent motor performance in infants born preterm. Pediatr Phys Ther. 2000;12:150-7.

100. Rose RU, Westcott SL. Responsiveness of the Test of Infant Motor Performance (TIMP) in infants born preterm. Pediatr Phys Ther. 2005;17:219-24.
Correspondence:

Rosana Silva dos Santos

Av. Portugal, 245/C9

CEP 24325-140 - Niterói, RJ - Brazil

Tel.: +55 (21) 2617.1042

E-mail: rosana.ft@ig.com.br 